\title{
On Money, Tolls and Standards
}

I believe that the European commission of the Danube is the first instance on record of a commission composed of delegates from non-riverain powers having executive power, and administering a revenueas well as carrying on extensive works in an European river.

JOHN STOKES, 1866

\section{A Tour for Collecting Multilateral Financial Guarantees}

On 25 December 1868, Edward James Standen, the private secretary of John Stokes, Britain's delegate in the European Commission of the Danube (Commission), landed in Istanbul after a three-day voyage on board an Austrian steamer plying between the Danube and the Golden Horn. After attending religious and social meetings on Christmas Day, Standen proceeded with his mission - to obtain the signatures of various European statesmen on a contract guaranteeing the loan that the Commission had secured for funding its technical works in the Danube Delta. On Sunday 27 December, he called at the British, French and Italian embassies, and eventually, on 30 December, Safvet Pasha signed and sealed the guarantee on behalf of the Ottoman cabinet. ${ }^{1}$

Standen left Istanbul on 2 January and travelled, via Syra, Corfu and Brindisi, to Florence. Official business did not keep him very busy, as the contract was readily signed after an interview with Count Luigi Federico Menabrea, Italy's prime minister and minister for Foreign Affairs. The envoy revelled in some of the city's rich architectural and artistic heritage before setting off for Paris on 14 January with a 'bad cold and fearful headache'. Baron Adolphe d'Avril, France's delegate to the Commission, mediated the signing of the contract at

1 Edward James Standen, A Diplomatic Mission, 1868 with Various Diversions to Some Capital Cities of Europe, an archived version online at https://web.archive.org/web/20180501034619/ http://www.ourfamilymoves.org.uk/individual.php?pid=Ig\&ged=bouck-standen (visited on 15 December 2018). 
the French Foreign Ministry, and on 20 January Standen continued his journey to Berlin. Otto von Bismarck's signature was expected to follow in a couple of days, allowing Standen just enough time for sightseeing and social meetings. One final stop to go - London - in the special envoy's one-month tour de force was planned to secure the financial means necessary for completing the hydraulic works that had started at Sulina more than a decade earlier. ${ }^{2}$

Getting enough funding for these works took about the same amount of time, concluded by several European commissioners in September 1868 with a loan agreement with the London bankers Bischoffheim and Goldschmidt. Given the status of the debtor - an international organisation with a rather unique legal status and serving for a limited term - European delegates agreed amongst themselves to ask for the backing of their governments. It was not only a condition required by most creditors whom they had contacted, but also a great financial advantage for the international agency: it would 'reduce the interest to some 3 or 4 per cent', from 10-12 per cent in the absence of such support, and thus 'make the burden lighter' for repaying the loan. ${ }^{3}$

By the time the 1868 loan was contracted, the Commission had already become a financially independent institution, able to procure the financial means for its everyday activities, to draw its own annual budget, and to effectively use this financial self-reliance to further prolong its existence at the Maritime Danube. It is the aim of this chapter to detail the experimental financial dimension of the Commission's early history and to explain, along the second analytical layer - that of institutional history - the Commission's quest to become financially independent. Money collected for its security-driven programme contributed not only to completing hydraulic works in the river, but also to securing the IO's survival and its self-branding as a successful transnational organ.

This story also reveals a little-known episode of inter-imperial cooperation in one of Europe's peripheries, which resulted in irreversible steps being taken towards standardisation in global maritime shipping and trade. The Commission's example is relevant to current debates regarding the funding of IOs and their (in)dependence in relation to member states. As few of the world's current IOs are self-funded, ${ }^{4}$ details on the evolution of the Commission will contribute to putting recent discussions of taxing global

2 Ibid.

3 John Stokes, Autobiography (s.l. s.a.), 93 .

4 As it is now the case, to a large extent, with the World Intellectual Property Organization and the International Seabed Authority - Thordis Ingadóttir, 'Financing International Institutions,' in: Jan Klabbers and Åsa Wallendahl (eds.), Research Handbook on the Law of International Organizations (Cheltenham 2011), 121-122. 
commons for increasing international cooperation into historical context. ${ }^{5}$ Not least of all, money itself has, as Madeleine Herren put it, a 'border crossing and networking function, ${ }^{6}$ placing the Commission's financial transactions into the realm of transnational history.

The 1856 Paris Treaty established Ottoman sovereignty in the Danube Delta, and during a meeting of European plenipotentiaries (27 March 1856) the Porte's delegates, Aali Pasha and Mehmed Djemil, pledged that the imperial government would gladly provide the financial advances needed to cover the Commission's technical works. ${ }^{7}$ When the seven commissioners convened at Galați in November 1856, the Ottoman delegate Ömer Fevzi Pasha made a similar pledge. There was no need to look for money elsewhere, as suggested by the Austrian agent, Franz Karl von Becke, who had proposed sharing the costs between the seven Great Powers. ${ }^{8}$

Ömer Pasha reserved for his government the right to pay for the hydraulic works completed on Ottoman territory, but his colleagues insisted that the Commission maintained its full autonomy in asking for whatever amount of money was needed to complete its task and in directing its spending. After a quick estimate, a committee of the British, Russian and Sardinian delegates requested from the Porte an advance of 100,000 ducats (about 1,200,00o francs), half for immediate expenses and half for the works that were to start in early 1857. The first allowance served to organise the institution's Secretariat and Technical Department and to purchase equipment and materials, such as dredging machines, steam tugs, hydraulic instruments and coal. ${ }^{9}$ Karl Hermann Bitter, the Prussian delegate, was elected to serve as the Commission's treasurer,

5 See for example Richard Bird, Global Taxes and International Taxation: Mirage and Reality, ICTD Working Paper 28 (Brighton 2015).

6 Madeleine Herren, “'They Already Exist”: Don't They? Conjuring Global Networks Along the Flow of Money,' in: Isabella Löhr and Roland Wenzlhuemer (eds.), The Nation State and Beyond: Governing Globalization Processes in the Nineteenth and Early Twentieth Centuries (Dordrecht 2012), 43-62.

7 Congrès de Paris 1856 (Paris 1856), 9-10.

8 The National Archives of Romania, Galați Branch, Protocols of the European Commission of the Danube (hereafter PECD), Protocol 2 (and appendix), 5 November 1856.

9 Ibid., Protocol 3 (and appendix), 7 November 1856. 
and his colleagues acted as auditors until qualified bureaucrats could take over such financial duties.

To secure the institution's much needed cash-flow and to run current financial operations, Bitter mediated an agreement with Joseph Hamperk, a Danish subject and the manager of a bank in Moldavia. Hamperk agreed to lend small amounts of money to the Commission (at 5 per cent interest and $1 / 2$ per cent commission) and to deposit its cash (at 4 per cent interest). ${ }^{10}$ However, the Ottoman Treasury sent its first advances in 1857 through a rival Moldavian entrepreneur, who was also available to act as the organisation's 'official' banker."1

Despite the commissioners' repeated protests, by June 1857 the Porte had only advanced about 20,000 ducats $(240,000$ francs $),{ }^{12}$ while the Commission made orders and paid for state-of-the-art hydraulic equipment in London, Vienna and Budapest, relying on borrowed funds that amounted to 20,775 ducats (ca. 250,000 francs). Including salaries already paid, the Commission was in default. Hamperk eventually denounced the preliminary agreement, the Commission sent an official letter of protest to the Porte, and Britain's commissioner Stokes left to seek ambassadorial support in Istanbul. ${ }^{13}$

The commissioners needed more than the Ottomans' verbal benevolence to keep the institution running. Its administrative bureau already numbered sixteen employees (secretaries, archivists, clerks), and as many again were working in the Technical Department. Their salaries plus the material costs of offices, supplies, correspondence and travel etc. were estimated at 34,0oo ducats (408,00o francs) a year, ${ }^{14}$ a total that did not include the Commission's main operational task: to install hydraulic works in the Maritime Danube.

Financial relations with the Ottoman government continued along similar lines until 1860. The Commission submitted regular payment requests, which the Porte covered with great tardiness, usually after the intervention of European ambassadors to Istanbul. Trying to limit the financial burden on the imperial Treasury, the Ottoman authorities started to account for all supplies (coal and timber) provided in kind, and even to take over the acquisition (at lower prices, it was hoped) of the equipment ordered by the Commission.

\footnotetext{
$10 \quad$ Ibid., Protocols 7 and 16, 17 December 1856 and 26 February 1857.

11 Ibid., Protocols 10 and 11, 12 January and 3 February 1857.

12 Ibid., Protocols 18, 26, 27 and 35, 7 March, 16 April, 27 April and 16 June 1857.

13 Ibid., Protocol 41, 29 June 1857.

14 Ibid., Protocol 43 (and appendix), 11 July 1857.
} 
In reply to the continuous pleas for stability and predictability in the organisation's budget, the tribute that the Principalities of Moldavia and Wallachia owed to their suzerain power, the Ottoman Empire, was assigned for the Commission's expenses. Nevertheless, there were no clear procedures regarding its payment, and things barely improved, as the two vassal governments insisted that they had already paid to the Porte more than the value of their due obligations. The Commission secured its cash-flow with money borrowed from local bankers, more often than not on onerous terms. In September 1859, the commissioners discussed the financial issue once more, and pleaded, yet again, for regular funding. The Commission's current shortage was 'a serious obstacle which could compromise the institution's [provisional] works', then underway at Sulina. ${ }^{15}$

Several solutions were taken into consideration: Édouard-Philippe Engelhardt, the French delegate, proposed inducing the Ottoman government to take a special loan for the exclusive use of the Commission; Britain's Stokes advised contracting a loan collectively guaranteed by the seven powers; Russia's Henrik d'Offenberg believed that all financial requests had to be directed to the Ottoman Treasury, which was bound to pay its dues. ${ }^{16}$ Preference was given to the British commissioner's proposal, as it was vital to have the money run by 'European' agents, and not rely on sluggish and unreliable Ottoman methods. If that solution was unsuccessful, the others were to be tried.

Faced with permanent financial insecurity, the Commission managed to carry out its technical programme through the commissioners' ability to borrow private money, and by pressing the Porte to pay the bills of change already issued for the technical equipment purchased or for the works completed at Sulina. All in all, between November 1856 and June 1860 the Ottoman Treasury spent on the Commission's account a total of about 317,000 ducats (3,740,000 francs), money that covered the IO's administrative costs, its preliminary technical studies, and the provisional works underway at Sulina. ${ }^{17}$

The Porte had good reason to retard and even question paying for all these costs. When in 1856 , in good faith, its diplomats pledged to advance funds for the Commission's expenses, the general belief was that the hydraulic works to be done in the Danube Delta were simple and inexpensive, and that the

\footnotetext{
15 Ibid., Protocol 108, 7 November 1859.

16 Ibid., Protocols 100 and 103, 29 July and 2 September 1859.

17 La Commission Européenne du Danube et son œuvre de 1856 à 1931 (Paris 1931), 121-122.
} 
Commission would terminate them in two years. In fact, the Ottoman Treasury came to pay for an increasingly robust and bureaucratic organisation, with several dozen well-paid European employees, who all had reason to state that their agenda was more complicated than anticipated and to claim that they needed more time (and money) to complete their tasks. It pretty much looked like 'extorting' imperial money for well-paid bureaucrats and experts working in a borderland where foreign interests greatly exceeded Ottoman ones.

The Ottoman compliance with these financial requests is even more remarkable given the great problems that the imperial budget had at the time. It was an early phase of the first external borrowing period $(1854-1876),{ }^{18}$ and the Porte was faced with large deficits. To advance the Commission's agenda, which was a collective venture of Europe's Concert of Powers, European ambassadors to Istanbul acted as an Ottoman Public Debt Administration (OPDA) avant la lettre. ${ }^{19}$ Their constant pressure in this informally institutionalised environment was fuelled by the dispatches regularly received from Galați. Ambassadors did make the Porte pay the external debt that it owed for removing navigational insecurity from the Lower Danube, but at the price of weakening the Ottoman state even more.

The 1856 Paris Treaty stipulated that the Commission was to determine fixed duties to be levied for covering the costs of works and establishments needed 'for the facility and security of navigation'. The commissioners discussed the question several times but decided to postpone the introduction of a tax until the organisation could improve the state of the Sulina channel, and thus make shipmasters pay for services and benefits they would actually get. The debates had some moral overtones, but there was solid economic reasoning in trying to keep the Maritime Danube as a low-priced alternative for the export of grain at a time when the construction of a railway between the Danube and the Black Sea seemed to deprive the river of its most lucrative business (see Chapter 6). ${ }^{20}$

18 Sevket Pamuk, The Ottoman Empire and European Capitalism, 1820-1913: Trade, Investment and Production (Cambridge 1987), 59-60.

19 For the OPDA, see Murat Birdal, The Political Economy of Ottoman Public Debt: Insolvency and European Financial Control in the Late Nineteenth Century (London and New York 2010) and Giampaolo Conte and Gaetano Sabatini, 'The Ottoman External Debt and Its Features under European Financial Control (1881-1914), Journal of European Economic History 43.3 (2014): 69-96.

20 John H. Jensen and Gerhard Rosegger, 'British Railway Builders along the Lower Danube, 1856-1869,' Slavonic and East European Review 44.106 (1968): 105-128. 
A provisional tariff was drafted in 1858 , but it was only in 1860 that the effects of the engineer-in-chief's works resulted in a visible increase of the navigable depth over the Sulina bar. It was a difficult period for the Commission's treasury, and the commissioners decided to introduce a tax that would provide the institution with a small, but regular income. This revenue could serve as a guarantee for a larger loan, which the local branch of a British bank seemed willing to give.

The tariff was designed following constructive discussions between the seven commissioners and, in the end, it was a simple and just system for international shipping. ${ }^{21}$ It was based on a double sliding scale, 'varying according to the size of the vessels and the depth of the entrance'. Commercial ships were classified depending 'on their draught of water as represented by their tonnage', and classes of ships were taxed in relation to the depth of water over the Sulina bar. ${ }^{22}$ The dues varied between 0.75 and 3.25 francs per ton, depending on the size of the vessel, and the commissioners stuck to the equally moral and economic principle that vessels had to pay according to the extent to which they are benefited by the works.' ${ }^{23}$ The shipping tariff was to include the other dues paid at Sulina (compulsory pilotage and the lighthouse service), and it was to be applied from September 1860 onwards. ${ }^{24}$

The IO's real success was being able to collect the taxes on its own account. The Navigation Cash Office in Sulina had to be administered by an agent appointed by the Commission, and its accounts were audited by the Ottoman government. ${ }^{25}$ 'European administration' was one of the conditions imposed by the British bank with which the Commission negotiated a loan, which stemmed from the commissioners' total mistrust in the integrity and professionalism of Ottoman employees. Ömer Pasha and the Porte accepted the arrangement on a provisional basis, to avoid new accusations that they were hindering the completion of the Commission's technical programme ${ }^{26}$ and to save the already overburdened Ottoman budget.

Financial autonomy, provisional as it was, changed the way the Commission acted in relation to its overall institutional identity. Not only had it to be more active in disseminating information on its activity, regulations and tariffs to

21 The National Archives of the United Kingdom (TNA), Foreign Office, FO 78/3216, unnumbered (hereafter unn.) (John Stokes to Earl Russell, Galați, 11 July 186o).

22 Stokes, Autobiography, 79.

23 Stokes, 'The Danube and Its Trade,' Journal of the Society of Arts 38.1954 (2 May 189o): 575.

24 PECD, Protocols 114 and 116 (and appendix), 15 June and 5 July 1860.

25 TNA, FO 78/3216, unn. (Stokes to Russell, Galați, 11 July 1860); La Commission, 89.

26 PECD, Protocol 116, 25 July 1860. 
the entrepreneurial community trading in the Black Sea basin, but it also had to carefully consider its sources of income and make cost-effective choices in its expenses. With the creation (1861) of the Inspectorate of Navigation (a department that supervised shipping on the section under the Commission's jurisdiction - see Chapter 7), a new, though much smaller source of income was represented by the fines paid by the shipmasters that violated the IO's regulations.

Since 1861, the Commission operated based on an annual budget of revenues and expenses. Income varied considerably. In the 186os, for example, natural factors, such as bad crops due to floods or droughts, were doubled by the instability in the United Principalities (Romania), during a period of agrarian reforms and political unrest, and on the world grain market. ${ }^{27}$ This tied the organisation to the political and economic stability of territories in the Danubian basin, and especially to the young nation-states along the Lower Danube. Commissioners had such large geopolitical considerations in mind, but they also looked for further standardisation in how the organisation collected its taxes.

\section{$5 \quad$ Standardising the European Tonnage Measurement}

Imposing the tariff and making shipmasters pay was one of the Commission's most difficult tasks, and it took a while to create proper international legislation, accepted by all powers interested in Danubian navigation. Another issue stemmed from the need to have a fair and proportionate taxation for all flags, as stipulated by the 1856 Paris Treaty. In the 1860 tariff, tolls were based on the ships' size, and several categories of tonnage were introduced. However, as there were no uniform standards for measuring a ship's tonnage in Europe and vessels arriving in Sulina presented papers issued by various national maritime authorities, it became vital to agree on a clear methodology for tonnage measurement.

In fact, deciding on a proper measurement of commercial ships was a thorny issue for all maritime nations. A British governmental commission led by George Moorsom was appointed in 1849 to establish rules for securing greater uniformity in the measurement and registration of vessels, at a time when the steamship industry was booming, and differences between sailing ships and steamers created problems for all port authorities. The Commission's recommendations (the so-called 'Moorsom system') were legalised in Great Britain in

27 See infra. 
1854. The basic principle was to have ships taxed according to their tonnage or cargo capacity. As an average English ton of cargo $(1,015 \mathrm{~kg})$ occupied a volume of about 100 cubic feet $\left(2.8 \mathrm{~m}^{3}\right)$, a ship's gross register tonnage was represented by its total internal volume (in cubic feet) divided by 100. The net register tonnage was the commercially productive part of a ship after deducting from the gross register tonnage the volume of the space used for the vessel's machinery and boiler spaces. ${ }^{28}$

In 1860 the Commission introduced this system, based on the information provided in the ships' papers. In the absence of proper documents, estimates were made by the Sulina Harbour Master, with the concurrence of local consular authorities and support of two other shipmasters (one preferably of the same nationality as the measured ship's master). A conversion table between different European units of measurement was also provided. ${ }^{29}$

However, skippers complained of inequities resulting from this system of calculation, and European commissioners asked for the support of their governments in solving the disparity. Stokes, for example, persuaded the British Board of Trade 'to take measurements according to English rules, of the vessels of foreign nations, so as to establish a comparison between the English tonnage and that of other nations'. He further worked to compile a conversion table, which allowed for a comparative view on ships' sizes. ${ }^{30}$

The conversion table was revised in May 1862 according to the measurements done in British ports to determine the proportion between the English register tonnage and that adopted in other countries. A total of 1,757 vessels of eighteen different flags were measured according to the two methods used in Great Britain: rule I applied for empty ships (for 442 vessels) and rule II for laden ships (for 1,315 vessels). The new table showed the average of the calculations between the tonnage indicated in their national certificate and the one issued in Britain. ${ }^{31}$ The table was periodically revised by the Navigation Chest at Sulina, as the correction coefficients became more accurate due to the increased number of vessels measured. This, however, did not change the need for further international standardisation, as

28 Aji Vasudevan, Tonnage Measurement of Ships: Historical Evolution, Current Issues and Proposals for the Way Forward, MA dissertation, World Maritime University (Malmö 2010), 18-19 (online at http://commons.wmu.se/all_dissertations/214, visited on 15 September 2018).

29 PECD, Protocol 116 (appendix), 5 July 1860.

3o Stokes, Autobiography, 79-81.

31 PECD, Protocol 143, 8 May 1862. 
the real remedy for these inequalities will be found in the adoption by all nations of one system of measurement so that the register ton will have but one meaning. A mixed scientific commission might be ordered to examine the different system, and having reported upon the best, a common understating might be come to, and a date fixed after which shipowners should be bound to have all their vessels remeasured. ${ }^{32}$

When the Greek authorities introduced the Moorsom system, and the Italians chose the French one, the Commission analysed the desirability 'of an official communication being made to it of any change in the system of measuring vessels which may hereafter be adopted by any country'.33 Such a meeting did take place when, in 1873, an International Tonnage Commission assembled in Istanbul to settle uniform measurement rules for the tonnage of ships passing through the Suez Canal. Stokes was one of the British delegates, as it 'had always been a work that interested me very much. His experience in running IOs proved helpful, and together with Baron d'Avril, the French delegate in both the Commission and the Istanbul Tonnage Commission, Stokes imposed the Danube Commission's procedures for 'the guidance of our discussions in this big Commission', which numbered twenty-four delegates from the world's leading twelve maritime nations. After lengthy discussions, most of the delegates voted for applying to the Suez a version of the so-called 'Danube Rule,' and Stokes bargained for a compromise acceptable to the Suez Canal Company's management, its shareholders and the community of international ship-owners. ${ }^{34}$

It took a long time to achieve global standardisation in tonnage measurement, but it is worth mentioning that the Commission pushed in the direction of a voluntary consensus. ${ }^{35}$ At a time when governments, companies and private individuals required, for different reasons, more uniformity in how the

32 TNA, FO 78/3218, unn. (Stokes to Russell, Galați, 25 March 1862); Stokes, Autobiography, 79-81.

33 TNA, FO 78/3223, unn. (Stokes to Lord Stanley, Galați, zo December 1867).

34 Percy Hetherington Fitzgerald, The Great Canal at Suez. Its Political, Engineering, and Financial History, vol. II (London 1876), 131-243 (Chapter XVII, The Tonnage Question); Stokes, Autobiography, 110-112; Joseph A. Obieta, The International Status of the Suez Canal (The Hague 1970), 56.

35 On consensus, see Craig N. Murphy and JoAnne Yates, The International Organization for Standardization (ISO): Global Governance through Voluntary Consensus (London and New York 2009); for the introduction of the Moorsom system in the Ottoman Empire and the role of the 1873 Istanbul conference, see İlhan Ekıncı, 'Osmanli deniz ticaretinde ölçü birimlerinin batililașmasina bir örnek: kile'den tonilatoya, Moorsom usulü'nün uygulanmasi,' Journal of International Social Research 4.17 (2011): 311-324. 
world was to be imagined and measured, ${ }^{36}$ one of the earliest IOs was doing the same. The drive came from economic rationality ${ }^{37}$ and the commissioners' interest in consolidating the finances of the organisation.

With unpredictable sources of income in its early history and faced with many uncertainties regarding its future, the Commission's bureaucrats started to collect statistics as a way of proving the efficiency of the institution's technical and normative works. Organising the thousands of ships that called at Sulina each year into meaningful categories proved extremely difficult. When the tariff was introduced in 186o, it needed to be based on an accepted standard. The natural choice was the British norm, that of the largest maritime power of the time. With this translated into costs, the commissioners felt it was their duty to invite governments to cooperate, both for the benefit of their own merchants and ship-owners, and for that of the Commission itself.

Reliable statistics, in which not only the number, but also the tonnage of ships was recorded, were vital in pro-active institutional thinking. They started to play an important role in shaping the budget of the organisation and its policies. As Stokes put it in his memoirs, his detailed statistical reports 'very much influenced the decisions of my colleagues'. ${ }^{38}$ The Commission collected relevant data from all over Europe and designed conversion tables that encouraged further research from interested private and governmental parties. By employing its own surveyors to gauge ships, the organisation underlined its objective to fairly tax all its clients and contribute to having more uniformity in tonnage measurement.

As 'standards' are considered 'central mechanisms of international governance', ${ }^{39}$ this example proves how institutionalising tonnage measurement ${ }^{40}$ set an example, soon adopted by larger international maritime ventures, such as the Suez and Panama Canal companies.

36 See for example Martin H. Geyer, 'One Language for the World. The Metric System, International Coinage and the Rise of Internationalism, 1850-1900,' in: Geyer and Johannes Paulmann (eds.), The Mechanics of Internationalism in the Nineteenth Century. Culture, Society, and Politics from the 1840s to the First World War (Oxford 2001), 55-92 and Bob Reinalda, Routledge History of International Organizations: From 1815 to the Present Day (Abingdon and New York 2009), 96-106.

37 Sidney Pollard, 'Capitalism and Rationality: A Study of Measurements in British Coal Mining, ca. 1750-1850,' Explorations in Economic History 20.1 (1983): 110-129.

38 Stokes, Autobiography, 100.

39 Kenneth W. Abbott and Duncan Snidal, 'International "Standards" and International Governance,' Journal of European Public Policy 8.3 (2001): 345-370.

40 Stefan Timmermans and Steven Epstein, 'A World of Standards but Not a Standard World: Toward a Sociology of Standards and Standardization,' Annual Review of Sociology 36 (2010): 69-89. 
During the period $1856-1860$, the Commission managed to secure its cash-flow thanks to small loans from private banks in Galați. This system was nevertheless inappropriate for getting a bigger loan that would allow the engineer-in-chief to complete the provisional works he had started at Sulina. The seasonality of the Danubian grain trade, with increased shipping (and consequently more revenues) in the summer and autumn months, added further financial pressure, as the hydraulic works had to be started in spring, when the Commission's treasury was usually empty.

The commissioners had discussed the possibility of contracting a bigger loan, but the organisation lacked the material securities requested by capitalists. In July 1860, when the Commission voted to impose the tariff and use this steady income as a guarantee for a loan, preliminary arrangements had been made with two British entrepreneurs based in Galați, A.L. Powell and H.A. Jackson, the local director and manager respectively of the Ottoman Bank, the largest financial house active in the Ottoman Empire. ${ }^{41}$ It is possible that personal relations between the two capitalists and some of the commissioners assisted in concluding the agreement, as Jackson was later to serve as director of the Commission's Navigation Chest for fifteen years (1874-1889). The bank agreed to lend to the Commission a sum of 60,000 ducats (about 711,000 francs), at an interest rate of 12 per cent per annum, and 1 per cent commission. The Commission pledged to introduce the navigation tariff and to collect shipping dues on its own account. All available resources, after saving the sums for institutional costs, were used to repay the loan. If the revenues were not sufficient, the Sublime Porte had to cover the difference, until the Ottoman Bank was fully reimbursed of both the capital and interest. ${ }^{42}$ The conditions were onerous, but the loan secured the lead engineer with the funds needed for completing the provisional dykes at Sulina. Two additional contracts led to the bank supplementing the original amount, reaching a total of about $1,370,000$ francs lent to the Commission in 1860 and $1861 .{ }^{43}$

The technical works were opened during a ceremony in September 1861 (Chapter 4), but they were far from being completed. This was not only due to their provisional nature, but also the need to secure a deeper passage for the

41 For the Ottoman Bank and the state debt, see Edhem Eldem, 'Ottoman Financial Integration with Europe: Foreign Loans, the Ottoman Bank and the Ottoman Public Debt,' European Review 13.3 (2005): 431-445.

42 PECD, Protocol 116 (appendix 3), 25 July 1860.

43 La Commission, $165^{-166 .}$ 
increasing size of commercial ships with the transition of the global fleet from sail to steam. It was a period of great uncertainty regarding the Commission's future, and more money was needed for its ongoing expenses. As the Ottoman Bank was unwilling to increase its stipends, the commissioners looked unsuccessfully for funds on the capital markets of Vienna, Paris and London. An offer came from the Nord Deutsche Bank of Hamburg, willing to lend the amount of 800,000 mark banco (about 1,500,00o francs). A confidential agent of the bank, a juridical expert called Octavio Schrœder, took part in one of the Commission's meetings, but he objected to the commissioners' lack of clear authority from their governments to raise loans. His request was that they obtain their cabinets' approval of the protocol to which the loan contract was annexed. As Stokes wrote to the British Foreign Office, 'it was distinctly understood that such approval should not imply a guarantee of the loan, but simply a formal recognition of the power of the commission to contract loans, and to engage the produce of the Sulina tariff to their repayment'.44 The financial conditions were more convenient than for the previous loan (an interest rate of 6 per cent per annum and 5 per cent commission), and the Commission granted the bank a pre-emption right on the taxes collected at Sulina, and mortgaged its movable and immovable properties to guarantee the loan. ${ }^{45}$

In November 1865, a Public Act was finally accepted by all seven commissioners, after four years of bargaining with the Ottoman delegate. It was a veritable 'Constitution' (Chapter 3), endowing the Commission with supranational attributions that were in clear violation of the Porte's sovereignty. It also referred to the proceeds of the Sulina tariff, which were to be used: a) by priority and preference for the repayment of the loans contracted by the Commission for its works; $b$ ) to cover the expenses of the Commission's administration and maintenance of the works and establishments; and c) 'to the liquidation of the advances made to the Commission by the Sublime Porte'. Any surplus was to be held in reserve for future expenses with the prolongation of the Sulina piers or by the carrying out of other works decided by the Commission or the authority that was to succeed it. ${ }^{46}$ This statement of the organisation's financial priority was meant to support its further access to the capital market, by officialising the use of the Sulina revenues as collateral for its loans.

44 TNA, FO 78/3218, unn. (Stokes to Russell, Galați, 6 June 1862).

45 PECD, Protocol 144 (and the appendix), 20 May 1862.

46 Hertslet's Commercial Treaties: A Complete Collection of the Treaties and Conventions, and Reciprocal Regulations, at Present Subsisting Between Great Britain and Foreign Powers, vol. 12 (London 1871), 889. 
Faced with a shortage of revenues in 1865 , the Commission contracted a small loan in December 1865, when Henry Maynard of London, a relative of Stokes, agreed to advance to the Commission about 250,000 francs. The interest rate was 8 per cent per annum, and the loan was guaranteed with the proceeds of the Sulina tariff. ${ }^{47}$ This secured the Commission its short-term cash-flow, but it needed to get a larger loan of about 3,000,000 francs to fund the completion of the Sulina works.

\section{$7 \quad$ Political Turmoil and a Test on the International Bond Market}

Things seemed to progress favourably, and the Commission was close to getting an advantageous loan in Germany, when the ousting of Prince Alexandru Ioan Cuza and the political unrest that ensued in Romania in February 1866 'brought matters to a stand-still, as capitalists are unwilling to send their capital into an unsettled country'. Although the Commission had no direct connection with the Romanian state, its financial resources depended 'intimately and directly on the welfare and prosperity' of that country. ${ }^{48}$ In March 1866 things did not look very promising for the Commission, which desperately needed cash to fund the works scheduled for the spring season.

Optimism returned in April, when the Nord Deutsche Bank of Hamburg offered a loan of 6o,ooo ducats, with an interest rate of 6 per cent, to be repaid in five years starting on 1 January 1867 . However, in a complicated international context, the loan depended on the preservation of peace on the continent. ${ }^{49}$ Eventually, with the start of the Prussian-Austrian war, the contract was broken off, and the commissioners had to find another source of funding.

The solution was to raise the needed cash by issuing bonds with an interest rate of 10 per cent per annum, redeemable in two years and bearing interest every six months. They were announced on 30 May 1866 but met with little response from the public. Bonds to the amount of 15,000 ducats were purchased in the following couple of months, mostly by employees of the Commission or their relatives, friends and acquaintances across Europe. A local banker, Abramovitz, offered to take bonds to the amount of 20,000 ducats, on condition that 12,000 ducats were paid in Romanian Treasury bonds issued in 1864 and 1865 and redeemable in the next year. Although this alternative was extremely

47 TNA, FO 78/3222, unn. (Stokes to the Earl of Clarendon, Galați, 1 February 1866).

48 Ibid., unn. (the same, 29 March 1866).

49 Ibid., unn. (the same, 7 April 1866). 
distasteful to the commissioners, the offer was accepted. ${ }^{50}$ This system of raising capital continued during the next year, so all in all the Commission got a total of about $1,558,800$ francs by issuing bonds. ${ }^{51}$

Recent studies on the beginnings and emergence of the international bond market in the nineteenth century focus on governmental bonds and the security clauses associated with state guaranteed loans, such as the Greek loans of 1833 and 1898, the Ottoman loan of 1855 , the Egyptian loan of 1885 , and the Chinese loan of $1895 .^{52}$ No reference, however, is made to the case of the Commission, which, from the early 1860 on onwards, enjoyed a large degree of financial autonomy and state-like behaviour in its liquid jurisdiction.

\section{Towards Collective Financial Security}

Negotiations for the loan continued, but they proceeded with difficulty as bankers were interested in the hard assets that the Commission could use as guarantees. In the autumn of 1866, the commissioners decided to ask for the support of their governments, faced with the futility 'of again attempting negotiations for a loan without the aid of the governments':

We are well aware that up to the present time each government has distinctly disclaimed any pecuniary responsibility in the loans effected by the Commission and that the great part of the Powers have refused to become guarantors for a loan for the Danube Works. On the other hand, the Governments have decided, in approval of the recommendation of the Conference of their Ambassadors at Paris on the 28th of March of this year, that the permanent works for ensuring and extending the improvements already effected in the Sulina mouth and channel, are to be terminated and the European commission dissolved, in five years from the spring of 1866 . To give effect to this double decision, the Commission must have money. ${ }^{53}$

5o Ibid., unn. (the same, 20 June 1866).

$5^{1} \quad$ La Commission, 167.

52 See for example Rui Pedro Esteves and Ali Coșkun Tunçer, 'Eurobonds Past and Present: A Comparative Review on Debt Mutualization in Europe,' Review of Law \& Economics 12.3 (2016): 659-688.

53 PECD, Protocol 189 (and the appendix), 15 October 1866; see also the report of Engelhardt to the French Foreign Office, Centre des Archives diplomatiques de Nantes, Représentant de la France auprès de la Commission Européenne du Danube, Série B, file 10, f. 453-454 (29 October 1866). 
Instructed not to engage their governments' pecuniary responsibilities, the commissioners felt obliged to submit a joint memorandum to their superiors, with a view to obtaining a collective guarantee for the required loan. In his report to London, Stokes referred to the very small amount of liability that such a guarantee would require, if ever needed, as well as to the uniqueness of the creditor (see motto above), which eliminated the risks of similar requests being made. ${ }^{54}$

The memorandum was not favourably received by European cabinets, and all attempts to get an unguaranteed loan failed. Stokes visited London in May 1867 and discussed at the Foreign Office and Board of Trade the possibility of convincing interested governments to pay themselves for the works in exchange for the reduction of Danubian tolls, as they had done for the redemption of the Stade dues in 1861 and the Scheldt toll in 1863. His proposal to have a contribution regulated in accordance with British interests in the Danube's navigation was, however, a complicated solution, although the Board of Trade seemed interested in the offer. ${ }^{55}$

Stokes discussed this proposal in Paris and Vienna, but he was not very encouraged by the response. Becke, Austria's Finance Minister and former Danube commissioner, considered the solution reasonable, but given his country's difficult financial situation, found it hard to obtain 'the consent of the Austrian and Hungarian chambers' for it. ${ }^{56} \mathrm{~A}$ common action for getting a collective guarantee by the three powers seemed more appropriate.

Negotiations continued throughout 1867 but offers were far from satisfactory. It was clear that governmental support would reduce the interest rate and the term of repayment from about twenty to twelve years. ${ }^{57}$ By January 1868 , with the involvement of its new commissioner, Baron d'Avril, France supported the idea of a collective guarantee, and d'Avril discussed it in Vienna with Becke, who also agreed to it, even if it would only be supported by Britain, France and Austria-Hungary. 58

54 TNA, FO 78/3222, unn. (Stokes to Stanley, Galați, 2 November 1866).

55 Ibid., FO $78 / 3_{2223}$, unn. (the same, 17 May 1867).

56 Ibid., unn. (the same, Vienna, 29 September 1867).

57 Ibid., FO 78/3224, unn. (the same, 14 January 1868).

58 Centre des Archives diplomatiques de La Courneuve (CADC), Commission Européenne de Danube (CED), File 9, f. 26-27 (Vienna, 26 January 1868). 
D'Avril proceeded to Galați, while his government continued to work towards securing larger diplomatic support for a collective guarantee. The response from Berlin was encouraging: although Prussia was not so directly interested in Danube navigation, its government would support the Commission to complete the task established by common consent in 1856 . Similar pledges came from Florence and Istanbul, while Russia withheld from any action, though it did not intend to hinder a European agreement to this end. ${ }^{59}$

In February 1868 the commissioners of Austria-Hungary, France and Great Britain convened to conclude a convention defining and recording the extent of the obligations to be incurred by the supporting powers. This was an instrument to be 'submitted to the parliaments or chambers of the countries undertaking the guarantee for their assent, and eventually will form the basis of the conditions under which the loan will be raised. ${ }^{60}$ The negotiators were endowed with full powers from their governments, and also looked at the example of the common statement between the British and French governments relative to the 1855 Ottoman loan. The preliminary agreement was concluded in March 1868, which specified the financial details of the loan, the term for which the guarantee would hold good, and the annuity for which the governments would be responsible. The document was signed on 30 April 1868 by six commissioners (bar the Russian one), and on 2 May 1868 the Commission analysed the bank's offer which its agent, Henry Maynard, had been negotiating. The loan was granted by the London bank of Bischoffheim and Goldschmidt, who agreed to lend a total of $3,375,800$ francs for the completion of the Sulina works. The money was to be paid in six instalments and carried an interest rate of 4 per cent per annum, plus a commission of 1 per cent for the middleman. ${ }^{61}$

The loan agreement was voted for in the national parliaments of the signatory powers, a decision which further contributed to spreading the word about the organisation's accomplishments. In the French Parliament, the rapporteur of the commission that analysed the government's proposal, Pierre Albert de Dalmas, considered that France could not stay away from such an 'important and civilising work', and insisted on the need for further international cooperation on monetary policies. ${ }^{62}$ His interest came, most probably, from another

\footnotetext{
59 Ibid., f. $5^{2-61 .}$

6o TNA, FO 78/3224, unn. (Stokes to Stanley, Galați, 15 February 1868).

61 PECD, Protocol 214 (and the appendix), 3 August 1868; La Commission, 167-168. The full text in Convention for the Guarantee of a Loan to Complete the Works at the Sulina Mouth and Branches of the Danube (London 1868).

62 CADC, CED, File 9, f. 174-179 ('Rapport fait au nom de la Commission chargée d'examiner le projet de loi relatif à la garantie de l'emprunt à contracter par la Commission européenne du Danube').
} 
important initiative concerning the establishment of international standards, the creation of the Latin Monetary Union in 1865 and the need for further economic integration. ${ }^{63}$

The convention was ratified in the following months, but by the autumn of 1868 the bankers insisted on having the act of guarantee signed by a member of each government, not only by their Danube commissioners. ${ }^{64}$ By November, the details of Standen's tour around Europe were set, as presented in the introduction to this chapter.

This story is relevant for the effects of formal governmental guarantees on the so-called 'empire effect'. According to some economic historians, British colonies could access the capital market in London more easily and borrow at lower interest rates as compared with other independent countries. ${ }^{65}$ Other scholars look for the 'guarantee effect', the interest rate advantage that independent (non-colony) countries had if the British government provided guarantees for their bonds. ${ }^{66}$ In the case of the Commission, as this narrative shows, such an effect clearly existed. In their efforts to secure sufficient resources for the completion of the hydraulic works completed at Sulina, European commissioners managed to mobilise both state support and private money for a transnational hydraulic accomplishment that represented a further guarantee for the IO's survival.

\section{9}

\section{Complete Financial Independence}

The Commission funded its hydraulic works with money taken from the loans mentioned above, and by the early 1870 s, at the completion of its first technical programme, its budget was in constant surplus (Table 3 ). The 1868 loan, not due to be returned until 1883, was one of the main reasons for the prolongation of the Commission when its previous term expired in 1871 .

63 Marc Flandreau, 'The Economics and Politics of Monetary Unions: A Reassessment of the Latin Monetary Union, 1865-71, Financial History Review 7.1 (2000): 25-44.

64 TNA, FO 78/3224, unn. (Stokes to Stanley, Galați, 12 October 1868).

65 Niall Ferguson and Moritz Schularick, 'The Empire Effect: The Determinants of Country Risk in the First Age of Globalization, 1880-1913,' Journal of Economic History 66 (2006): 283-312.

66 Huseyin Al, 'Was There a Guarantee Effect for the Ottoman Loans in the Nineteenth Century?', Australian Economic History Review 52.2 (2012): 191-208. 
In 1878 , the Berlin Treaty transferred the Danube Delta from the Ottoman Empire to newly independent Romania, which was also accepted as a member state in the Commission. The organisation preserved its former rights, prerogatives and obligations in complete independence of the territorial authority'.67 Its large financial autonomy turned into fully-fledged independence, as the Ottoman auditors were replaced with those of the Commission itself. An international conference hosted in London in 1883 further prolonged the Commission, which became a de facto permanent IO (Chapter 8). ${ }^{68}$ The repayment of the 1868 loan was terminated in December 1882, whereas the Ottoman advances were fully repaid by 1887 . With a large annual financial surplus, the organisation started a second hydraulic programme in the $188 \mathrm{os}$, designed to deepen the navigable channel along the entire Maritime Danube (Chapter 4).

European commissioners used the tariff to balance the Commission's budget and changes in taxation were introduced in $1863,1865,1867,1870,1880,1882$, $1884,1887,1889$, 1902 and 1908 . Regularly updating the tariff was a complex process, which had to consider several economic and political factors, such as the transition from sail to steam, the larger tonnage of commercial steamers, the competition of railways and the economic policies of local states. ${ }^{69}$

Most of the Commission's revenues (about 96 per cent) came from the navigation tariff, and the rest from fines and interest on the organisation's reserves. As for its expenses, a large share of the money went for operational costs (Table 3): about 55 per cent for the hydrotechnical works at Sulina and along the river, and 25 per cent for the services responsible for shipping safety along the Maritime Danube. This explains to a large extent why the Commission was regarded as a successful international organ that managed to collect and spend financial resources efficiently. ${ }^{70}$

67 The text of the Berlin Treaty in Documents Diplomatiques. Affaires d'Orient. Congrès de Berlin 1878 (Paris 1878), 291-293; Dimitrie A. Sturdza, Recueil de documents relatifs à la liberté de navigation du Danube (Berlin 1904), 123-124.

68 Navigation du Danube. Conférence et Traité de Londres. Février-Mars $188_{3}$ (Paris 1883), $65^{-}$ 68; Sturdza, Recueil de documents, 472-474.

69 La Commission, $138-151$.

70 Soviet historiography had a rather different reading of the Commission's financial efficiency - M.V. Pochkaeva, Mezhdunarodno-pravovou rezhim sudokhodstva na Dunae (Moscow 1951), 24. 
TABLE 3 Financial situation of the Commission, 1861-1914 (annual average, francs)

\begin{tabular}{llll}
\hline Period & Revenues & Expenses & Balance \\
\hline $1861-1865$ & $1,082,603$ & $1,894,950$ & $-812,347$ \\
$1866-1870$ & $1,358,264$ & $1,805,604$ & $-447,340$ \\
$1871-1875$ & $1,386,746$ & $1,131,077$ & 255,670 \\
$1876-1880$ & $1,777,989$ & $1,074,717$ & 703,272 \\
$1881-1885$ & $1,966,559$ & $1,470,807$ & $495,75^{2}$ \\
$1886-1890$ & $1,916,301$ & $1,718,327$ & 197,974 \\
$1891-1895$ & $2,467,679$ & $2,537,807$ & $-70,128$ \\
$1896-1900$ & $1,983,268$ & $2,073,073$ & $-89,805$ \\
$1901-1905$ & $2,439,263$ & $2,291,889$ & 147,374 \\
$1906-1910$ & $2,527,111$ & $2,576,962$ & $-49,851$ \\
$1911-1914$ & $2,662,529$ & $2,768,859$ & $-106,329$ \\
\hline
\end{tabular}

SOURCE: LA COMMISSION EUROPÉENNE DU DANUBE ET SON OEUVRE DE 1856 À 1931 (PARIS 1931), 498-499 (ANNEXE III)

TABLE 4 Expenses of the Commission, 1861-1914 (francs)

\begin{tabular}{lrr}
\hline Expenses & Amount & Per cent \\
\hline Internal administration & $7,210,574$ & 6.94 \\
Navigation establishments & & \\
Hospital $^{\mathrm{a}}$ & $26,033,721$ & 25.04 \\
Technical services $^{\mathrm{b}}$ & $2,776,767$ & 2.67 \\
Definitive works voted in 1865 & $41,660,107$ & 40.08 \\
Cuttings (second hydraulic programme) & $3,375,000$ & 3.25 \\
Other expenses & $11,820,376$ & 11.37 \\
Interest and costs for loans & $5,518,028$ & $5 \cdot 31$ \\
Telegraph line built in 1857 & $4,234,671$ & 4.07 \\
Subventions for the employees' pensions fund & 88,870 & 0.09 \\
Total & $1,233,382$ & 1.19 \\
\end{tabular}

a It includes the internal services of the Commission, such as the Navigation Inspection, Harbour Master Office, Navigation Chest, pilotage and lighthouses.

b Regular works at Sulina and the maintenance of river navigability along the Sulina branch. SOURCE: LA COMMISSION, 494-497 (ANNEXE II) 
The case study presented in this chapter is illustrative of the financial dimension of a security regime. Security expenditure, one of the most difficult aspects of international cooperation, requires fairly sharing the costs between partners. The Commission avoided this problem when it became financially autonomous and then independent. This status was necessary given the unpredictability and unreliability of financial advances made by local governments. With total mistrust in the capacities of Ottoman and Romanian officials to coordinate the financial activities of the Commission, commissioners looked for autonomy in financial decision-making, and gradually got it, due to the tedious ways in which the Ottoman Treasury covered its requests for funding. The Commission smartly speculated on the several ambiguities in the text of the 1856 Paris Treaty and imposed a tariff that was used to fund the hydraulic works at Sulina. This deprived the Ottoman state of its sovereign rights and a steady source of income, but it secured necessary funding for the organisation, which had the resources to further experiment in international administration. After all, a solid relation links money and sovereignty. ${ }^{71}$

With this status accepted by the Ottoman state, commissioners could seek the support of their governments in what would become a remarkable episode of imperial cooperation. Everything started with the initiative of several commissioners, who convinced their cabinets of the importance, but also of the cost-free impact for national budgets of such cooperation on behalf of a civilising hydraulic mission. When, in 1868, governments and national parliaments of Europe's Great Powers discussed the loan agreement for the Commission, they also came into closer contact with the works that the organisation was doing in the Danube Delta. If until then such information was confined to state departments, in 1868 they reached a broader political audience, with beneficial results for regime survival at the Maritime Danube.

This financial independence relied on keeping the Commission's main clients - shipmasters and merchants - happy with its activity. The introduction of the tariff in 1860 was another instance of fruitful transnational cooperation between the seven commissioners, the IO's bureaucrats and the commercial circles from the Lower Danube. The attempt to maintain perfect equality for all flags, as stipulated by the Paris Treaty, made all parties interested in sticking to the moral grounds that the tariff invoked: the idea that one paid exactly for the shipping safety one got. It needed to be profitable to pay taxes, and

71 John Grahl, 'Money as Sovereignty: The Economics of Michel Aglietta,' New Political Economy 5.2 (2000): 291-316. 
this required commissioners to look for harmonising international practices related to the measurement of ships' tonnage. It was a thorny issue at the time amongst maritime nations, complicated by the transition from sail to steam. The solution imposed by the Commission was to look for further transnational cooperation on the topic and to establish a perfect equivalency among different flags. Professional measurement of ships all over Europe and the standardisation of measurement procedures followed suit. The Commission strongly encouraged a trans-governmental exchange of information, though a more durable agreement on the topic was only possible later in the nineteenth century, after the completion of the Suez Canal.

The lasting contribution of the Commission was that it secured Europe as a whole by creating norms and regulations, including in financial terms, regarding the navigation of international waterways that were later transposed into the national laws of member states and of other countries around the globe. Through their bottom-up actions, European commissioners proved that international cooperation was possible and profitable in pursuit of limited but manageable ends. 